\title{
Penyisihan Kadar Amoniak dalam Limbah Cair Industri Pupuk Menggunakan Sequencing Batch Reactor
}

\author{
Robby Sudarman, Herawati Budiastuti*, Nancy Siti Djenar, Efniarsi S. Panggalo, \\ Ajie Nurhasyim A. \\ Jurusan Teknik Kimia, Politeknik Negeri Bandung, Jl. Gegerkalong Hilir, Bandung Barat, Indonesia, \\ 40012 \\ *E-mail: herabudi@polban.ac.id
}

\begin{abstract}
ABSTRAK
Sifat toksik nitrogen amoniak dalam limbah cair berbahaya bagi kehidupan sehingga perlu untuk dihilangkan. Pada penelitian ini penyisihan kadar amoniak yang tinggi dalam limbah cair industri pupuk dilakukan melalui proses nitrifikasi dan denitrifikasi menggunakan Sequencing Batch Reactor (SBR). Dua reaktor SBR digunakan dimana pada reaktor pertama (R1) dilakukan pengadukan dan pada reaktor kedua (R2) dilakukan aerasi. Hasil penelitian menunjukkan bahwa pada pembebanan 0,787 mg amoniak/L/hari dan Hydraulic Retention Time (HRT) 20 hari, efisiensi penyisihan kadar amoniak mampu dicapai pada kisaran 71,26\%-90,91\% (R1) dan $62,32 \%-92,21 \%$ (R2). Pengukuran pH pada HRT 20 hari berada pada rentang 8,25-8,65 pada R1 dan $\mathrm{pH}$ 8,34-8,73 pada R2. Pada HRT 15 hari, efisiensi penyisihan kadar amoniak efluen pada R1 menurun yaitu dari $90,89 \%$ menjadi $86,81 \%$ dan pada R2 menurun dari $90,59 \%$ menjadi 40,99\%. Pada HRT 15 hari, efisiensi penyisihan kadar amoniak pada R1 lebih baik dibandingkan pada R2 yang disebabkan adanya penambahan aerasi pada R1 di akhir penelitian.
\end{abstract}

Kata kunci: amoniak, limbah cair, industri pupuk, sequencing batch reactor

\begin{abstract}
The toxic nature of ammonia nitrogen in liquid waste is dangerous for life, so it needs to be eliminated. In this study, the removal of high ammonia levels in the fertilizer industry wastewater was carried out through a process of nitrification and denitrification using the Sequencing Batch Reactor (SBR). Two SBR reactors were used where the first reactor (R1) was stirred and the second reactor (R2) was aerated. The results showed that at a load of $0.787 \mathrm{mg}$ of ammonia/L/day and 20 days of Hydraulic Retention Time (HRT), the efficiencies of removal of ammonia levels were achieved in the range of $71.26 \%-90.91 \%$ (R1) and $62.32 \%-92.21 \%(\mathrm{R} 2)$. The $\mathrm{pH}$ measurements at 20 days of HRT were in the range of 8.25-8.65 at R1 and pH 8.34-8.73 at R2. At 15 days of HRT, the effluent ammonia level removal efficiency at R1 decreased from $90.89 \%$ to $86.81 \%$ and at R2 decreased from $90.59 \%$ to $40.99 \%$. At 15 days of HRT, the efficiency of ammonia level removal at R1 was better than that in $\mathrm{R} 2$ due to the addition of aeration to $\mathrm{R} 1$ at the end of the study.
\end{abstract}

Keywords: ammonia, liquid waste, fertilizer industry, sequencing batch reactor

\section{PENDAHULUAN}

Limbah cair yang dihasilkan oleh buangan industri di Indonesia merupakan masalah dengan dampak berbahaya bagi manusia dan lingkungan. Seiring jumlah industri yang terus meningkat, limbah yang dihasilkan juga terus meningkat (Aka dkk., 2017). Salah satu zat pencemar buangan industri adalah amoniak yang terdapat dalam limbah cair industri pupuk. Amoniak dalam jumlah yang tinggi tidak diinginkan karena 
memiliki sifat toksik yang dapat merusak kehidupan biota air (Omairah dkk., 2019).

Nitrogen-amoniak, baik nonterionisasi $\left(\mathrm{NH}_{3}\right)$ dan terionisasi $\left(\mathrm{NH}_{4}{ }^{+}\right)$, merupakan polutan utama pada sumber air minum. Amoniak merupakan indikator penting kualitas air yaitu dapat menunjukkan kemungkinan pencemaran bakteri, selokan dan kotoran hewan (Fu dkk., 2012).

Senyawa-senyawa nitrogen, amoniak dan nitrit, merupakan zat yang menurunkan kadar oksigen terlarut dalam sistem perairan (Melki dkk., 2018). Pembuangan senyawa-senyawa ini ke perairan penerima tanpa pengolahan yang tepat dapat menyebabkan ketidakseimbangan dalam sistem ekologi alami yang meningkatkan eutrofikasi (Assefa dkk., 2019). Untuk itu, diperlukan sistem pengolahan limbah cair yang dapat menyisihkan kadar amoniak sehingga efluennya dapat memenuhi baku mutu sebelum dibuang ke badan air penerima (Fitriana dan Warmadewanthi, 2016).

Salah satu cara mengolah limbah cair yang mengandung amoniak tinggi adalah pengolahan dengan lumpur aktif. Teknologi pengolahan lumpur aktif memanfaatkan peran bakteri aerob untuk mendegradasi material organik yang terkandung di dalam limbah cair. Proses lumpur aktif akan menghasilkan bioflock atau sel baru yang mudah untuk diendapkan (Pranoto dkk., 2019).

Penerapan pengolahan limbah cair dengan lumpur aktif secara konvensional memiliki kendala-kendala dalam operasinya, seperti bulking yang memberikan dampak negatif terhadap kinerja pengolahan sehingga digunakan flotation pada sedimentasi untuk memisahkan lumpur dari efluen yang telah diolah. Hal tersebut menyebabkan kenaikan biaya dan operasi instalasi yang lebih kompleks (Essa, 2017).
Sequencing batch reactor (SBR) dapat menjadi solusi untuk mengatasi masalah-masalah operasional dari proses lumpur aktif konvensional. Sequencing Batch Reactor (SBR) adalah proses pengembangan dari Lumpur Aktif (Activated Sludge), yakni proses pengolahan limbah cair secara biologi aerob dengan memanfaatkan mikroorganisme dalam kondisi tersuspensi (suspended growth) (Alfiah dan Sinatria, 2017). Prinsip pengoperasian SBR berdasarkan pada pengisian dan pengosongan reaktor (Huseini dkk., 2018). Pengolahan dengan SBR ekonomis karena siklus operasinya yang mencakup pengisian, aerasi, pengendapan, dan pengeluaran efluen terjadi dalam satu reaktor yang sama (Mulyani dkk., 2018). Penggunaan SBR dapat menghemat lebih dari $60 \%$ biaya operasional yang diperlukan bagi proses lumpur aktif konvensional dan dapat menghasilkan kualitas efluen yang tinggi dalam waktu aerasi yang sangat singkat (Dutta dan Sarkar, 2015).

Kelebihan SBR adalah fleksibilitas waktu operasi, karena dapat disesuaikan dengan volume limbah maupun volume reaktor. Dengan demikian sistem SBR lebih hemat lahan, hemat energi, maupun tenaga operator serta biaya. Dalam aplikasi di lapangan untuk mengolah limbah cair, proses SBR dapat menggunakan reaktor tunggal maupun menggunakan beberapa reaktor, sesuai kebutuhan.

SBR dengan sistem alirannya yang terputus tidak membutuhkan clarifier dan pompa resirkulasi lumpur untuk menambahkan/mengembalikan sebagian lumpur aktif ke dalam reactor, seperti yag terjadi pada sistem lumpur aktif konvensional. SBR mampu menyisihkan kandungan organik dalam air limbah dan juga mampu menyisihkan kandungan amoniak dalam limbah cair amoniak 
melalui proses nitrifikasi dan denitrifikasi secara simultan (Le dkk., 2015).

Dalam sistem pengoperasian SBR digunakan Hydraulic Retention Time (HRT) sebagai parameter penting yang menyatakan lamanya waktu keberadaan suatu kumpulan mikroba di dalam reaktor (Pan dkk., 2004). Nilai HRT menunjukkan tingkat keaktifan metabolisme mikroba dalam reaktor dan mempengaruhi aliran nutrisi, produk dan bahan kimia yang tidak bereaksi melalui reaktor (Nelabhotla dkk., 2020). Berdasarkan alasan di atas, maka dalam penelitian ini SBR dipilih untuk mengolah limbah cair amoniak buangan industri pupuk. Penelitian ini bertujuan untuk mengetahui pengaruh penurunan HRT terhadap efisiensi ( $\eta$ ) penyisihan kadar amoniak dalam limbah cair industri pupuk menggunakan Sequencing Batch Reactor (SBR) serta mengetahui pengaruh pengadukan dan aerasi pada SBR terhadap efisiensi penyisihan kadar amoniak dalam limbah cair industri pupuk.

\section{METODE}

Penurunan kadar amoniak dalam limbah cair industri pupuk dilakukan menggunakan proses nitrifikasi dan denitrifikasi dalam SBR. Metode yang digunakan adalah metode eksperimental skala laboratorium yang terdiri atas tiga tahapan meliputi: tahap persiapan, tahap eksperimen, dan tahap analisis.

\section{Tahap Persiapan}

Pada tahap persiapan dilakukan perancangan dan pembuatan SBR, penyediaan bahan dan peralatan, pengambilan limbah cair dan lumpur aktif, pengenceran limbah, serta penentuan kondisi operasi. Limbah cair yang digunakan berasal dari limbah cair industri pupuk yaitu PT Pupuk Kujang, sedangkan lumpur aktif berasal dari PT Insansandang Internusa.

SBR yang digunakan merupakan SBR skala laboratorium yang terbuat dari galon aqua yang bagian bahunya dipotong sehingga diperoleh volume total reaktor sebesar $15 \mathrm{~L}$, dimana volume aktif reaktor yang digunakan yaitu $12 \mathrm{~L}$. SBR yang dibuat sebanyak 2 buah, dimana pada SBR yang pertama (R1) dilakukan pengadukan sedangkan pada SBR yang kedua (R2) dilakukan aerasi. Skema SBR yang digunakan ditunjukkan pada Gambar 1.
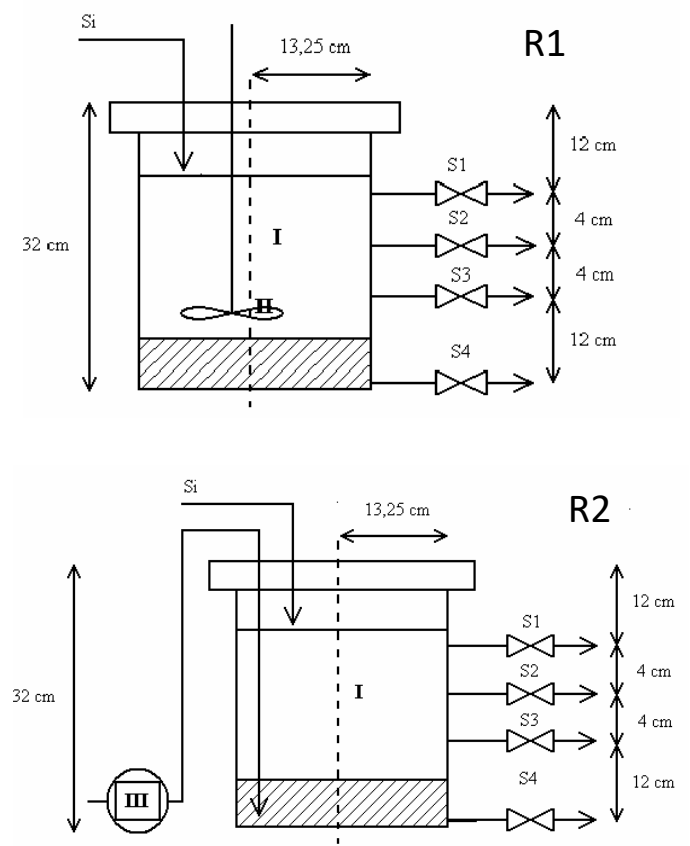

Gambar 1. Skema Sequencing Batch Reactor

Keterangan Gambar:

$\begin{array}{lll}\text { I }: \text { Reaktor } & \text { S1 } & \text { : Pengeluaran efluen } 1 \\ \text { II }: \text { Pengaduk } & \text { S2 } & \text { : Pengeluaran efluen } 2 \\ \text { III : Aerator } & \text { S3 } & \text { : Pengeluaran efluen } 3 \\ \text { Si : influen } & \text { S4 } & \text { : Pengeluaran efluen } 4\end{array}$

\section{Tahap Eksperimen}

Dua tahapan eksperimen yaitu tahap aklimatisasi dan tahap penurunan HRT. Tahap aklimatisasi dilakukan untuk mendapatkan kultur mikroorga-nisme yang telah mampu menyesuaikan diri dengan limbah yang akan diolah. HRT 20 hari ditentukan sebagai variabel awal 
proses. Penurunan HRT dilakukan untuk mengetahui kemampuan mikroba dalam mendegradasi limbah amoniak terhadap kenaikan konsentrasi dan volume limbah amoniak. Penurunan HRT dilakukan dari HRT 20 hari menjadi HRT 15 hari pada R1 dan R2. Penambahan aerasi pada R1 dilakukan pada HRT 15 hari (hari ke-8 sampai hari ke-15).

\section{Tahap Analisis}

Pada tahap ini dilakukan analisis terhadap efluen (limbah) yang telah didegradasi oleh mikroba (lumpur aktif) dalam reaktor. Parameter efluen meliputi kadar amoniak (mg/L), MLVSS (mg/L), kekeruhan (NTU), dan $\mathrm{pH}$. Kadar amoniak (mg/L) dianalisis menggunakan metode spektrofotometer UVVisible di laboratorium Balai Pengembangan Laboratorium Kesehatan Bandung dan di Pusat Penelitian Kimia LIPI Bandung, sedangkan parameter yang lain dianalisis di laboratorium Pengolahan Air dan Limbah Industri (PLI) Jurusan Teknik Kimia POLBAN. Nilai MLVSS ditentukan dengan metode gravimetri menggunakan furnace pada $600^{\circ} \mathrm{C}$, nilai kekeruhan diukur menggunakan turbidimeter, sedangkan nilai $\mathrm{pH}$ diukur menggunakan $\mathrm{pH}$ meter.

\section{HASIL DAN PEMBAHASAN Aklimatisasi}

Pada penelitian ini, aklimatisasi dilakukan dengan pembebanan $0,787 \mathrm{mg}$ amoniak/L/hari pada HRT 20 hari. Kondisi operasi ini dipilih pada awal proses penyisihan kadar amoniak dalam limbah cair dikarenakan mikroba lumpur aktif yang berasal dari PT Insansandang Internusa telah terbiasa mendegradasi limbah yang mengandung amoniak.

Proses aklimatisasi dimulai dengan mengkondisikan mikroba lumpur aktif tanpa pemberian limbah amoniak (influen) selama 2 hari. Hal ini dimaksudkan agar mikroba dapat mendegradasi sisa-sisa limbah tekstil yang masih terdapat di dalam lumpur aktif tersebut. Selain itu proses aklimatisasi juga dimaksudkan untuk mengkondisikan agar mikroba dalam keadaan malnutrisi tersebut siap menerima campuran glukosa dan limbah cair amoniak sehingga mikroba siap untuk menerima $100 \%$ limbah amoniak. Konsentrasi mikroba lumpur aktif baik yang ada di dalam reaktor maupun yang terbawa aliran efluen diketahui berdasarkan hasil analisis MLVSS.

Hasil penelitian menunjukkan bahwa proses aklimatisasi tercapai dalam 16 hari yaitu pada saat nilai MLVSS atau konsentrasi mikroba yang mampu dipertahankan dalam reaktor cenderung konstan yang menunjukkan bahwa mikroba telah mampu beradaptasi dengan limbah amoniak yang digunakan. Nilai MLVSS reaktor rata-rata sebesar 54.062 $\mathrm{mg} / \mathrm{L}$ pada R1 dan $60.854 \mathrm{mg} / \mathrm{L}$ pada R2. Konsentrasi MLVSS reaktor rata-rata pada R2 lebih besar dibanding MLVSS reaktor rata-rata pada $\mathrm{R} 1$ dikarenakan terpenuhinya kebutuhan oksigen pada R2 (yang dilakukan aerasi) sehingga membantu pertumbuhan mikroba yang lebih baik dibandingkan mikroba pada R1.

Konsentrasi mikroba di dalam reaktor (MLVSS reaktor) mampu dipertahankan lebih tinggi daripada konsentrasi mikroba yang ikut terbawa oleh aliran efluen (MLVSS efluen, Gambar tidak ditunjukkan). Hal ini menunjukkan bahwa mikroba yang biasanya mendegradasi limbah tekstil telah mampu beradaptasi dengan limbah amoniak sehingga diketahui bahwa proses SBR pada percobaan ini telah berlangsung dengan baik.

Efisiensi penyisihan kadar amoniak terhadap waktu ditunjukkan pada Gambar 2. Secara keseluruhan nilai efisiensi penyisihan kadar amoniak efluen meningkat seiring dengan bertambahnya waktu. Nilai efisiensi penyisihan kadar amoniak efluen berkisar antara 71,26\% 
hingga $90,91 \%$ pada R1 dan antara $62,32 \%$ hingga $92,21 \%$ pada R2. Hal ini menunjukkan bahwa proses penyisihan kadar amoniak telah berlangsung dengan baik.

Pada Gambar 2 terdapat titik yang menunjukkan terjadinya penurunan nilai efisiensi penyisihan kadar amoniak efluen, yaitu pada hari ke-12. Pada hari

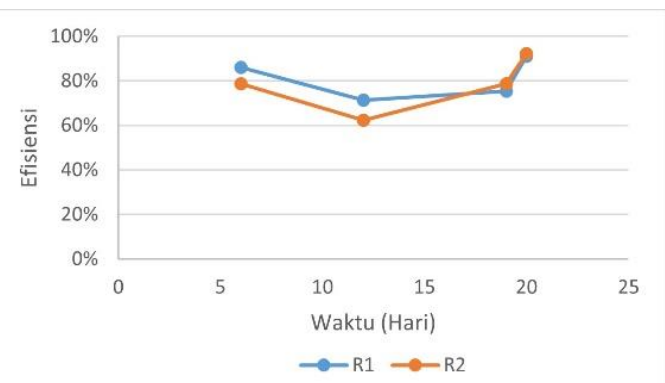

Gambar 2. Efisiensi Penyisihan Kadar Amoniak Efluen - HRT 20 Hari

ke-12 nilai efisiensi penyisihan kadar amoniak efluen turun dari 86,05\% menjadi $71,26 \%$ pada R1 dan dari $78,68 \%$ menjadi $62,32 \%$ pada R2. Hal tersebut dikarenakan adanya akumulasi sisa limbah yang tidak terdegradasi pada hari-hari sebelumnya sehingga menyebabkan penurunan efisiensi penyisihan kadar amoniak efluen namun pada hari ke-19 sampai hari ke-20 nilai efisiensi penyisihan kadar amoniak efluen meningkat kembali menjadi $90,91 \%$ pada R1 dan $92,21 \%$ pada R2. Hal tersebut menunjukkan bahwa mikroba pada R1 dan R2 telah mampu beradaptasi dan mendegradasi limbah amoniak dengan baik.

Pengaruh aerasi terhadap sistem SBR ditunjukkan oleh efisiensi penyisihan amoniak pada R2 yang lebih baik dibandingkan $\mathrm{R} 1$, yaitu pada $\mathrm{R} 2$ mampu mencapai penyisihan hingga 92,21\% sedangkan pada R1 mampu mencapai 90,91\%. Hal ini dikarenakan aerasi mampu membantu pertumbuhan mikroba sehingga menyebabkan kepadatan lumpur yang tinggi. Kepadatan lumpur yang tinggi dapat mengurangi rongga udara dalam lumpur, sehingga kondisi anoksik dapat tercapai. Selain itu, pengaruh aerasi pada R2 mampu membantu mikroba dalam mengatasi akumulasi limbah lebih baik dibandingkan pada R1. Hal tersebut ditunjukkan pada Gambar 2, dimana pada kedua reaktor terjadi penurunan nilai efisiensi penyisihan kadar amoniak efluen pada hari ke-12 akibat akumulasi, namun pada hari ke-19 nilai efisiensi meningkat kembali, yaitu pada R2 nilai efisiensi meningkat sebesar $16,48 \%$, (dari $62,32 \%$ menjadi $78,80 \%$ ), sedangkan pada R1 nilai efisiensi hanya mampu meningkat sebesar 3,99\% (dari $71,27 \%$ menjadi $75,26 \%)$.

Hasil analisis $\mathrm{pH}$ reaktor terhadap waktu ditunjukkan pada Gambar 3. Secara umum $\mathrm{pH}$ reaktor pada $\mathrm{R} 1$ dan $\mathrm{R} 2$ masih berada pada kisaran $\mathrm{pH}$ optimum berlangsungnya proses nitrifikasi dan denitrifikasi, yaitu antara 8,25 hingga 8,65 pada R1 dan antara 8,34 hingga 8,73 pada R2.

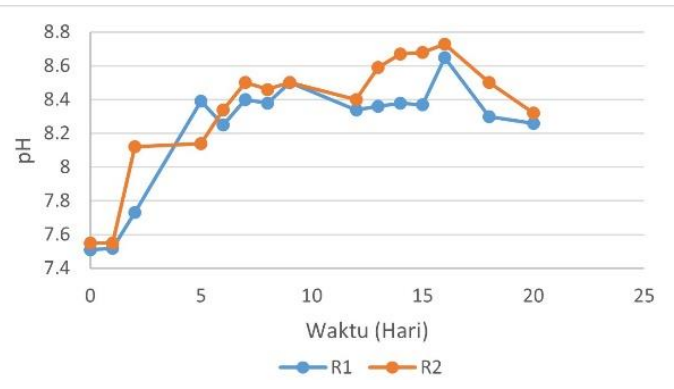

Gambar 3. Nilai pH Reaktor terhadap Waktu

$\mathrm{pH}$ optimum reaktor yang masih diperoleh menunjukkan bahwa proses yang berlangsung di dalam SBR (R1 dan R2) telah berjalan dengan baik. Sistem SBR dengan waktu tinggal yang lebih singkat dibandingkan dengan sistem lumpur aktif konvensional mampu menghasilkan efisiensi penyisihan kadar amoniak efluen yang cukup tinggi sehingga sistem ini dapat diterapkan sebagai alternatif sistem pengolahan limbah amoniak bagi industri. 


\section{Penurunan HRT}

Pengaruh kenaikan konsentrasi dan volume limbah amoniak (pembebanan) terhadap kemampuan mikroba dalam mendegradasi limbah amoniak diteliti dengan menurunkan HRT dari 20 hari menjadi 15 hari. Pada HRT 15 hari, nilai MLVSS reaktor dan efluen ditunjukkan pada Gambar 4 dan 5.

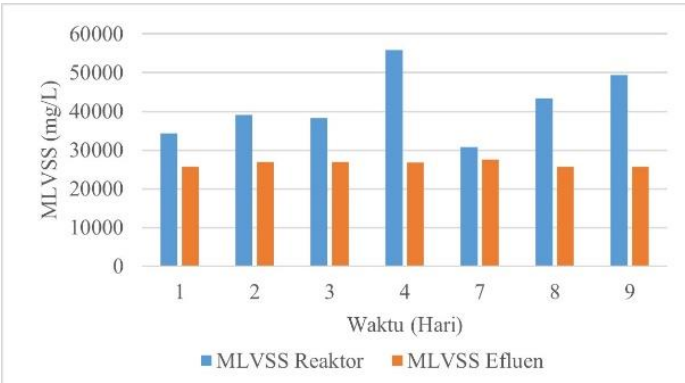

Gambar 4. MLVSS Reaktor Dan Efluen Terhadap Waktu (R1) - HRT 15 hari

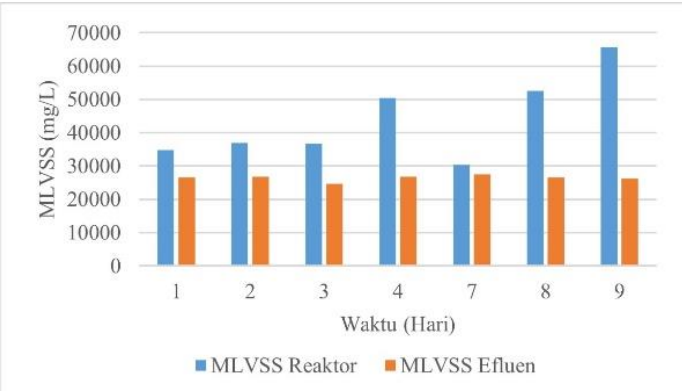

Gambar 5. MLVSS Reaktor Dan Efluen Terhadap Waktu (R2) - HRT 15 hari

Nilai MLVSS pada Gambar 4 dan 5 menunjukkan bahwa pada hari ke-1 sampai dengan hari ke-3, konsentrasi rata-rata mikroba yang ikut keluar bersama aliran efluen lebih dari $2 / 3$ kali konsentrasi rata-rata mikroba yang mampu dipertahankan di dalam reaktor. Hal ini menunjukkan bahwa proses SBR terganggu pada hari ke- 1 sampai dengan hari ke-3 dimana mikroba yang ada dalam reaktor mengalami shock terhadap kenaikan pembebanan sebesar 1,049 mg amoniak/L/hari dan penurunan HRT yang diberikan. Pada hari ke-4 sampai dengan hari ke-9 pada kedua reaktor menunjukkan bahwa mikroba sudah mulai mampu beradaptasi dengan adanya kenaikan pembebanan dan penurunan HRT tersebut.

Konsentrasi MLVSS rata-rata reaktor setelah adaptasi (hari ke-4 sampai dengan hari ke-9) pada R2 lebih besar dibandingkan dengan R1 yaitu pada R2 sebesar $56.193 \mathrm{mg} / \mathrm{L}$ sedangkan pada R1 sebesar $49.462 \mathrm{mg} / \mathrm{L}$. Hal ini dikarenakan masih terpenuhinya kebutuhan oksigen dalam R2 sehingga mampu membantu pertumbuhan mikroba lebih baik dibandingkan R1 meskipun adanya kenaikan pembebanan amoniak dan penurunan HRT.

Efisiensi penyisihan kadar amoniak terhadap waktu setelah kenaikan konsentrasi limbah amoniak ditunjukkan pada Gambar 6. Nilai efisiensi penyisihan kadar amoniak efluen pada awal pembebanan (hari ke- 1) lebih rendah jika dibandingkan dengan hari ke-20 pada pembebanan $0,787 \mathrm{mg}$ amoniak/L/hari, yaitu sebesar $86,07 \%$ pada R1 dan sebesar $68,97 \%$ pada R2. Rendahnya nilai efisiensi penyisihan kadar amoniak efluen pada hari ke-1 dikarenakan kondisi shock yang dialami mikroba terhadap kenaikan pembebanan amoniak dan penurunan HRT yang diberikan seperti yang dijelaskan pada kurva MLVSS (Gambar 4 dan 5).

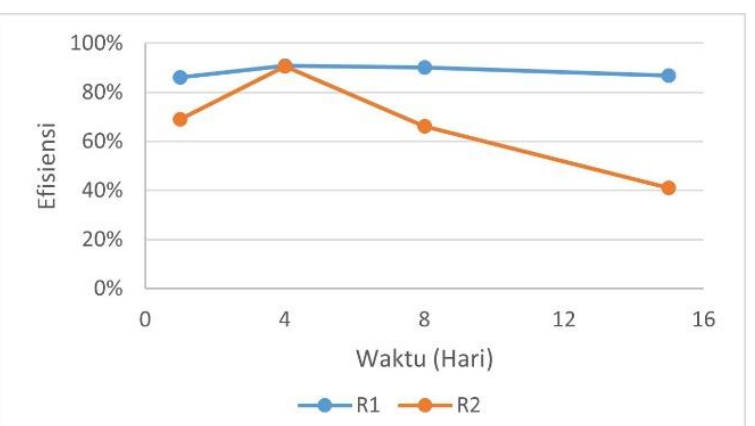

Gambar 6. Efisiensi Penyisihan Kadar Amoniak Efluen - HRT 15 Hari

Gambar 6 menunjukkan pada hari ke-4 nilai efisiensi penyisihan kadar amoniak efluen meningkat kembali yaitu menjadi $90,89 \%$ pada R1 dan $90,59 \%$ 
pada R2. Peningkatan efisiensi penyisihan kadar amoniak efluen tersebut menunjukkan bahwa mikroba sudah mulai mampu beradaptasi dengan adanya kenaikan pembebanan. Kemampuan mikroba beradaptasi terhadap kenaikan pembebanan ditunjukkan juga dengan adanya kenaikan nilai MLVSS R1 dan R2 (Gambar 4 dan 5).

Pada hari selanjutnya sampai dengan hari ke-15 secara umum nilai efisiensi penyisihan kadar amoniak efluen kembali menurun (Gambar 6). Pada R1 nilai efisiensi penyisihan kadar amoniak efluen menurun dari nilai $90,89 \%$ menjadi $86,81 \%$ dan pada R2 menurun dari $90,59 \%$ menjadi $40,99 \%$. Hal tersebut menunjukkan bahwa terjadi penurunan kemampuan mikroba dalam mendegradasi limbah.

Pada Gambar 6, setelah hari ke-4 nilai efisiensi penyisihan kadar amoniak efluen pada R2 menurun drastis. Hal tersebut disebabkan oleh menurunnya kadar oksigen terlarut dalam reaktor yang ditunjukkan oleh hasil pengukuran DO dalam reaktor menurun dari 5,88 $\mathrm{mg} / \mathrm{L}$ menjadi 3,08 $\mathrm{mg} / \mathrm{L}$. Penurunan nilai DO dikarenakan jumlah mikroba yang bertambah sangat tinggi dalam reaktor R2 dibandingkan dengan R1 seperti yang ditunjukkan juga pada Gambar 5 sehingga kebutuhan DO sudah tidak tercukupi.

Pada R1, setelah hari ke-4 juga terjadi penurunan nilai efisiensi penyisihan kadar amoniak (Gambar 6) namun bila dibandingkan dengan $\mathrm{R} 2$, penurunan efisiensi penyisihan kadar amoniak pada R1 tidak setajam pada R2. Hal ini disebabkan pada hari ke-8 di dalam R1 ditambahkan aerasi sehingga nilai DO meningkat dari $0,55 \mathrm{mg} / \mathrm{L}$ menjadi 5,16 mg/L. Berdasarkan hasil analisis tersebut dapat disebutkan kembali bahwa pengaruh aerasi pada
SBR lebih baik dibandingkan dengan pengadukan.

\section{SIMPULAN}

Aklimatisasi sistem SBR tercapai dalam waktu 16 hari dan berperan menghasilkan mikroba yang adaptif dengan limbah amoniak yang diolah dimana konsentrasi MLVSS reaktor ratarata pada $\mathrm{R} 1$ dan $\mathrm{R} 2$ berturut-turut sebesar $60.854 \mathrm{mg} / \mathrm{L}$ dan $54.062 \mathrm{mg} / \mathrm{L}$. Sistem SBR dapat digunakan oleh industri yang menggunakan sistem lumpur aktif konvensional dalam mengolah limbah amoniak.

Penurunan HRT berpengaruh terhadap efisiensi penyisihan kadar amoniak dalam sistem SBR dimana efisiensi pada HRT 20 hari cenderung lebih tinggi dibandingkan pada HRT 15 hari. Hal ini dikarenakan kondisi shock yang dialami mikroba terhadap kenaikan pembebanan amoniak.

Aerasi berpengaruh positif terhadap efisiensi penyisihan kadar amoniak dalam sistem SBR yaitu nilai efisiensi penyisihan kadar amoniak menggunakan aerasi mampu dicapai lebih tinggi dibandingkan dengan pengadukan.

Saran untuk penelitian selanjutnya agar digunakan reaktor yang tidak mempunyai lekukan-lekukan karena dapat menghambat pengendapan lumpur aktif dalam reaktor. Reaktor yang digunakan sebaiknya berwarna bening sehingga lebih memudahkan dalam pengamatan pengendapan lumpur.

\section{DAFTAR RUJUKAN}

Aka, H. A., Suhendrayatna, \& Syaubari. (2017). Penurunan Kadar Amonia Dalam Limbah Cair Oleh Tanaman Air Typha Latifolia (Tanaman Obor). Jurnal Ilmu Kebencanaan, 4(3), 72-75.

Alfiah, T. \& Sinatria, A. Z. (2017). Pengolahan Lindi Pios Menggunakan Sequencing Batch 
Reactor (SBR) pada Perbandingan F/M Rendah. Prosiding Seminar Nasional Sains dan Teknologi Terapan V. Institut Teknologi Adhi Tama Surabaya. ISBN 978-60298569-1-0.

Assefa, R., Bai, R., Leta, S., \& Kloos, H. (2019). Nitrogen removal in integrated anaerobic-aerobic sequencing batch reactors and constructed wetland system: a field experimental study. Applied Water Science, 9(136), 1-11.

Dutta, A., \& Sarkar, S. (2015). Sequencing Batch Reactor for Wastewater Treatment: Recent Advances. Curr Pollution Rep, 1, 177-190.

Essa, N. (2017). Aplikasi Sequencing Batch Biofilter Granular Reactor pada Pengolahan Limbah Cair Rumah Sakit dalam Skala Laboratorium. Surabaya:

Laporan Tugas Akhir, Departemen Teknik Lingkungan, Fakultas Teknik Sipil dan Perencanaan, Institut Teknologi Sepuluh Nopember.

Fitriana, A. R., \& Warmadewanthi, I. (2016). Penurunan Kadar Amonium dan Fosfat pada Limbah Cair Industri Pupuk. Jurnal Teknik ITS, 5(2), 107-111.

Fu, Q., Zheng, B., Zhao, X., Wang, L., \& Liu, C. (2012). Ammonia pollution characteristics of centralized drinking water sources in China. Journal of Environmental Sciences, 24(10), 1739-1743.

Huseini, M. R., Arifah, N., Pratiwi, W. A. (2018). Pengaruh Hidrotermal Sekam Padi Terhadap Produksi Biometana Pada AGS - SBR. Jurnal Konversi, 7(2), 17-23.

Le, H. T., Jantarat, N., Khanitchaidecha, W., Ratananikom, K., \& Nakaruk, A. (2015). Development of Sequencing Batch Reactor
Performance for Nitrogen Wastewater Treatment. Journal of Microbial \& Biochemical Technology, 7(6), 363-366.

Melki, Isnansetyo, A., Widada, J., \& Murwantoko. (2018). The significance of water quality parameters on the diversity of ammonia-oxidizing bacteria in the water surface of Musi river, Indonesia. AACL Bioflux, 11(6), 1908-1918.

Mulyani, H., Budianto, G. P., Margono, \& Kaavessina, M. (2018). Study of COD Removal Rate in Tapioca Wastewater Treatment by Sequencing Batch Reactor (SBR). Agritech, 38(3), 243-250.

Nelabhotla, A. B., Khoshbakhtian, M., Chopra, N., \& Dinamarca, C. (2020). Effect of Hydraulic Retention Time on MES Operation for Biomethane Production. Frontiers in Energy Research, 8(87), 1-6.

Omairah, R., Diansyah, G., \& Agustriani, F. (2019). Pengaruh Pemberian Amonia dengan Dosis Berbeda terhadap Pertumbuhan Fitoplankton Nannochloropsis sp Skala Laboratorium. Maspari Journal, 11(2), 41-48.

Pan, S., Tay, J. H., He, Y. X., \& Tay, S. T. (2004). The effect of hydraulic retention time on the stability of aerobically grown microbial granules. Letters in Applied Microbiology, 38, 158-163.

Pranoto, K., Pahilda, W. R., Abfertiawan, M. S., Elistyandari, A., \& Sutikno, A. (2019). Teknologi Lumpur Aktif dalam Pengolahan Air Limbah Pemukiman Karyawan dan Perkantoran PT Kaltim Prima Coal. Indonesian Mining Professionals Journal, 1(1), 61-66. 